\title{
Publisher Correction To: Disclosure of same- sex practices and experiences of healthcare stigma among cisgender men who have sex with men in five sub-Saharan African countries
}

John Mark Wiginton ${ }^{*}$, Sarah M. Murray², Ohemaa Poku², Jura Augustinavicius², Kevon-Mark Phillip Jackman², Jeremy Kane ${ }^{3}$, Serge C. Billong 4,5, Daouda Diouf ${ }^{6}$, Ibrahima Ba ${ }^{6}$, Tampose Mothopeng ${ }^{7}$, Iliassou Mfochive Njindam ${ }^{8,9}$, Gnilane Turpin ${ }^{8,9}$, Ubald Tamoufe ${ }^{9}$, Bhekie Sithole ${ }^{10}$, Maria Zlotorzynska ${ }^{11}$, Travis H. Sanchez ${ }^{11}$ and Stefan D. Baral ${ }^{8}$

\section{Correction to: BMC Public Health 21, 2206 (2021)} https://doi.org/10.1186/s12889-021-12151-3

During the publication of the original article [1], an error in the typesetting \& publication process resulted in several wrong citations in the background, method \& measures section.

The original article has been updated to rectify these errors.

The publisher apologizes for the inconvenience caused to the authors \& readers.

\section{Author details}

'Department of Health, Behavior \& Society, Johns Hopkins University Bloomberg School of Public Health, 624 N Broadway Street, Baltimore, MD 21205, USA. ${ }^{2}$ Department of Mental Health, Johns Hopkins University Bloomberg School of Public Health, Baltimore, MD, USA. ${ }^{3}$ Department of Epidemiology, Columbia University Mailman School of Public Health, New York City, NY, USA. ${ }^{4}$ Department of Public Health, Faculty of Medicine and Biomedical Sciences, University of Yaoundé I, Yaoundé, Cameroon. ${ }^{5}$ Central Technical Group, National AIDS Control Committee, Yaoundé, Cameroon. ${ }^{6}$ Enda Santé, Dakar, Senegal. ${ }^{7} T$ The
People's Matrix, Maseru, Lesotho. ${ }^{8}$ Center for Public Health \& Human Rights, Department of Epidemiology, Johns Hopkins University Bloomberg School of Public Health, Baltimore, MD, USA. ${ }^{9}$ Metabiota, Yaounde, Cameroon, Johns Hopkins Cameroon Program, Yaounde, Cameroon. ${ }^{10} \mathrm{MbabaneFHI} 360$,

Mbabane, Eswatini. ${ }^{11}$ Department of Epidemiology, Emory University Rollins School of Public Health, Atlanta, GA, USA.

Published online: 12 January 2022

\section{Reference}

1. Wiginton JM, Murray SM, Poku O, et al. Disclosure of same-sex practices and experiences of healthcare stigma among cisgender men who have sex with men in five sub-Saharan African countries. BMC Public Health. 2021;21:2206. https://doi.org/10.1186/s12889-021-12151-3.

\section{Publisher's Note}

Springer Nature remains neutral with regard to jurisdictional claims in published maps and institutional affiliations.

The original article can be found online at https://doi.org/10.1186/s12889021-12151-3.

\footnotetext{
*Correspondence: jwigint2@jhmi.edu

${ }^{1}$ Department of Health, Behavior \& Society, Johns Hopkins University Bloomberg School of Public Health, 624 N Broadway Street, Baltimore, MD 21205, USA

Full list of author information is available at the end of the article
}

(C) The Author(s) 2021. Open Access This article is licensed under a Creative Commons Attribution 4.0 International License, which permits use, sharing, adaptation, distribution and reproduction in any medium or format, as long as you give appropriate credit to the original author(s) and the source, provide a link to the Creative Commons licence, and indicate if changes were made. The images or other third party material in this article are included in the article's Creative Commons licence, unless indicated otherwise in a credit line to the material. If material is not included in the article's Creative Commons licence and your intended use is not permitted by statutory regulation or exceeds the permitted use, you will need to obtain permission directly from the copyright holder. To view a copy of this licence, visit http://creativecommons.org/licenses/by/4.0/. The Creative Commons Public Domain Dedication waiver (http://creativeco mmons.org/publicdomain/zero/1.0/) applies to the data made available in this article, unless otherwise stated in a credit line to the data. 